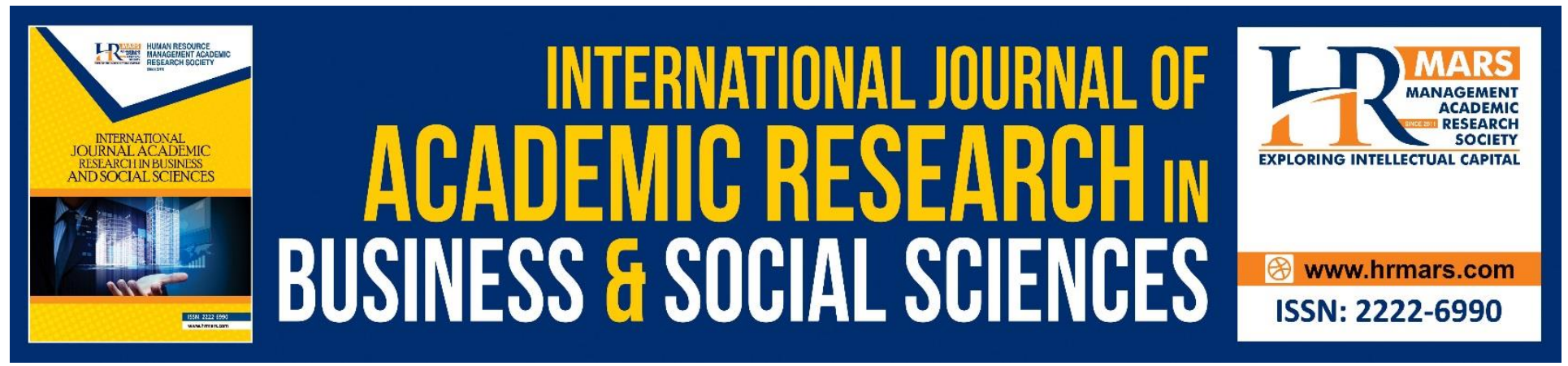

\title{
The Effects of Empowermnet, Work Culture, Responsibility and Motivation on the Professional Commitment of Vocational High School Teachers in Central Jakarta Municipality
}

Eryatun Koswara, Ma'ruf Akbar, and Yetti Supriyati

To Link this Article: http://dx.doi.org/10.6007/IJARBSS/v10-i14/7690

DOI:10.6007/IJARBSS/v10-i14/7690

Received: 20 April 2020, Revised: 27 May 2020, Accepted: 20 June 2020

Published Online: 27 July 2020

In-Text Citation: (Koswara et al., 2020)

To Cite this Article: Koswara, E., Akbar, M., \& Supriyati, Y. (2020). The Effects of Empowermnet, Work Culture, Responsibility and Motivation on the Professional Commitment of Vocational High School Teachers in Central Jakarta Municipality. International Journal of Academic Research in Business and Social Sciences, 10(14), 213-223.

Copyright: (C) 2020 The Author(s)

Published by Human Resource Management Academic Research Society (www.hrmars.com)

This article is published under the Creative Commons Attribution (CC BY 4.0) license. Anyone may reproduce, distribute, translate and create derivative works of this article (for both commercial and non-commercial purposes), subject to full attribution to the original publication and authors. The full terms of this license may be seen

at: http://creativecommons.org/licences/by/4.0/legalcode

Special Issue: WSTI2018 - Issues and Trends on Education, Science and Technology, 2020, Pg. 213 - 223 http://hrmars.com/index.php/pages/detail/IJARBSS

JOURNAL HOMEPAGE

Full Terms \& Conditions of access and use can be found at http://hrmars.com/index.php/pages/detail/publication-ethics 


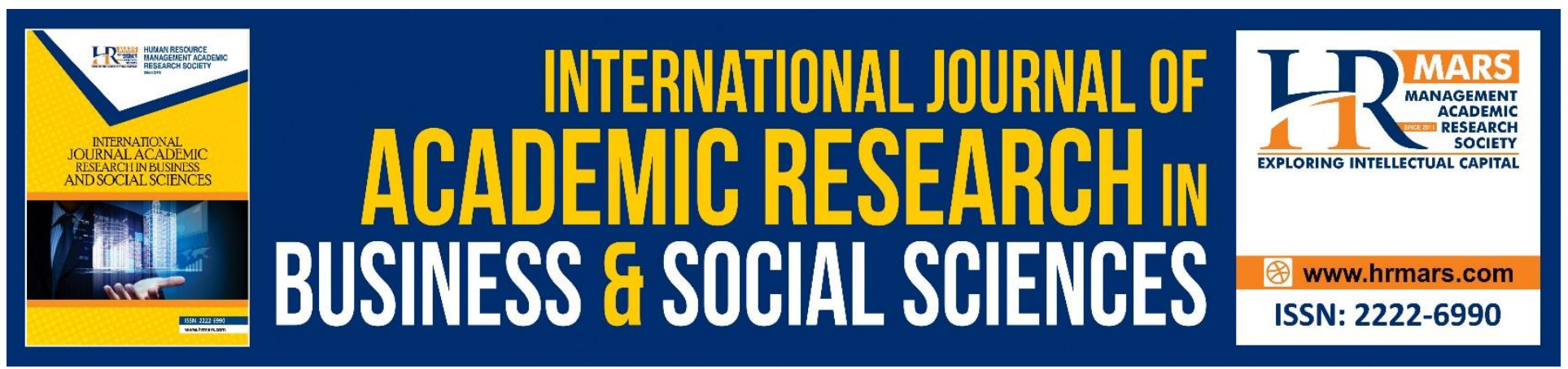

\title{
The Effects of Empowermnet, Work Culture, Responsibility and Motivation on the Professional Commitment of Vocational High School Teachers in Central Jakarta Municipality
}

\author{
Eryatun Koswara, Ma'ruf Akbar, and Yetti Supriyati \\ State University of Jakarta, Indonesia.
}

\begin{abstract}
The aim of this research is to examine the effects of empowerment, work culture, responsibility and motivation on the professional commitment of vocational high school teachers in Central Jakarta Municipality. This research attempts to answer the question of the professional commitment of vocational high school teachers. This research examined the organizational citizenship behaviours of 211 vocational high school teachers chosen from a vocational high school teacher population in Central Jakarta Municipality using a quantitative approach and path analysis method. The results of the hypothesis testing show that empowerment has a direct positive effect on professional commitment; work culture has a direct positive effect on professional commitment; responsibility has a direct positive effect on professional commitment; and motivation has a direct positive effect on professional commitment. Therefore, to improve the professional commitment of vocational high school teachers in Central Jakarta, empowerment, work culture, responsibility and motivation should be improved.
\end{abstract}

Keywords: Empowerment, Work Culture, Responsibility, Motivation, Professional Commitment.

\section{Introduction}

The main focus of the educational sector in Indonesia in facing the ASEAN Economic Community $(A E C)$ is the improvement of education quality in order to produce human resources of desired quality. The Indonesian nation is expected to be a productive, efficient and confident nation to be able to compete against other nations at the global stage, where business actors and workers from different corners of ASEAN compete against each other in the business world. Quality education will enable the Indonesian nation to keep up with globalization. Without reliable (professional) human resources, it is unlikely that Indonesian education will achieve the desired performance. Article 39 (2) of the Law Number 20 of 2003 on the National Education System defines an educator as a professional responsible for planning and implementing instruction, assessing learning outcomes, conducting coaching and training and carrying out research and civil services to the society. This is especially true with high school educators. 
Current development requires quality human resources fostering. Indonesia's competitiveness in the international competition and free trade is highly dependent on the outcomes of human resources fostering. The State makes an effort to produce quality mid-level human resources through vocational education. Some of the programmes of vocational high school revitalization in the province of DKI Jakarta include the following: managing vocational high school expertise competencies by opening new expertise competencies shooting up in the digital economy/e-commerce era; increasing state vocational high school capacity significantly from 22 per cent (of the overall vocational high school student population) to 45 per cent in 2022 through the construction of 42 New Units (USB) of vocational high school as contained under the Regional Medium-Term Development Planning of the Province of DKI Jakarta for the period 2018-2022; and enhancing vocational high school teachers' competencies (capacity building). Teachers are among the most crucial components of the educational system at school. A school's development is heavily reliant on teacher quality in terms of mastery of instructed materials and technique of material delivery to students. Teachers as the key to a school's success must be fully aware of their functions and responsibilities.

Head of the Agency for Human Resources Development and Education Quality Assurance (BPSDMPK-PMP) of the Ministry of Education and Culture Syawal Gultom admitted that the quality of Indonesian teachers currently is low. The results of the competency test conducted over the last three years prove Indonesian teachers' extremely low quality. Many of the teachers understood neither the substance of their knowledge nor the appropriate instructional model to be applied to students. He further explained Indonesia's educational qualifications. As of now, out of 2.92 million teachers, only 51 per cent pursued undergraduate education, while the remaining pursued lower education. There are many issues to be addressed when it comes to teachers. Not only education level but also their competencies are problematic. When a test was administered to teachers of all subjects, less than 50 per cent of the questions on average were answered correctly. A principal as a formal leader of an educational unit has the responsibility for the school's goals as they are responsible for the micro-management of education in the instructional processes at school. Thus, professional commitment in this case is (1) a belief in and acceptece of a profession's goals and values, (2) a willingness to exert a serious effort on behalf of a profession, and (3) an intention to maintain membership in a profession.

According to the explanation above, professional commitment is key to educating the lives of the Indonesian nation. The professional commitment of vocational high school teachers in the Central Jakarta Municipality is low. The authors were interested in investigating this by identifying the factors and variables affecting professional commitment.

\section{Literature Review \\ Professional Commitment}

Human resources are the key to the success of an organization. Thus, they are worth full attention in the preparation for facing the increasingly rapid development of education. Human resources serve as an essential foundation for an effective educational process. Chang and Choi define professional commitment as as psychological attachment to and identification with one's profession. Individuals with high levels of professional commitment are characterized as having a strong belief in and acceptance of profession's goals, a willingness to exert considerable effort on behalf of the profession, and a strong desire to maintain membership in the profession. 
Benligiray dan Sönmez define professional commitment as a belief in and acceptance of the values of the profession which is chosen, effort to actualise these values, desire to improve him/herself and determination to maintain membership in that profession. Çetinkaya, Özmen and Temel further define that professional commitment is shaped by four factors during professional experience and socialization process. These are a willingness to work, membership information (sustaining and protecting), believing in goals and values, and an ongoing career prospect. Similarly, Morrow P. and Goetz J. define professional commitment as as the extent to which one identifies with one's profession and accepts its values. Professional commitment is the level of belief in the values and purposes of a profession, a willingness to put professional purposes over the others and an intension to maintain membership in a profession. Thus an individual who is committed to their profession will perform a task based on the prevailing guidance, norms and rules.

According to the explanation above, the definition of professional commitment can be synthesized as one's belief in and acceptance of the values of the profession of their preference and their willingness to maintain membership in their profession with the following indicators: identifying with the profession, belief in the profession as well as values and integrity of the profession.

\section{Empowerment}

Improvement of human resources quality may be performed through education. The success of an educational process is closely tied to the significant role of educators (hereinafter teachers). Teachers have an essential role in the success of the instructions taking place at schools. Some studies in developing countries have provided evidence that teachers make the greatest contribution towards learning performance. Peter K. Mills and Gerardo R. Uungson state that empowerment has been credited with improving production and service quality and efficiency in a number of companies. However, this type change often encounters several obstcles. A frequent problem is opposition to the change from managers who fear loss authorithy and power. Fred Luthans defines empowerment as the authority to make decisions within one's area of responsibility with out first having to get approval from someone else. Empowerment can be stated as something that encourages ones to be further engaged in decision-making and activities relating to a profession. Every empowered individual is enabled to make decisions in a greater quantity and significance without having to refer to a senior. Jay A. Conger and Rabindra N. Kanungo as quoted by Ricard L. Daft dexcribe that increasing employee power heightens motivation for task accomplishment because people improve their own effectiveness, choosing how to do a task and using their creativity.

According to the aforementioned concepts, the definition of empowerment can be synthesized as an effort made in the utilization and development of employees' potential to improve their performance in achieving the organization's goals with indicators autonomy grant, resources exploitation and participation enhancement.

\section{Work Culture}

A culture is the essence of external and internal problem-solving carried out consistently by a group of individuals, who later pass it on to newer members as the right way to understand, think about and perceive every related problem. Meanwhile, work culture is a philosophy based on an outlook as values that turn into a nature, habit and driver instilled in a group and reflected in the attitude that turns into a behaviour, aspiration, opinion, view and action manifested as work. Ken Megil defines work culture as the common sense that a worker brings to work. The work culture 
consists of the shared attitudes toward work, the shared beliefs not about this workplace, but work in general, the common expectations about behavior, the rituals of work, the traditions of work, the way things have always been done. When workers leave one workplace and go to another, there may be minor changes in such things as dress, hours, wires and computers, and mores of talk around the water fountain.

Furthermore, Ken Megil defines that work calture is determined and driven by the machine, the mode of production. The owner/manager of the machines orchestrates the work, whether those machines are robots on the floor of the manufacturing plant or computers in cubicles. We can see this translated into the world of the Information Age where the computer and its capacities and configuration can dominate much of the way work is done today. Likewise, Pattigrew A. defines work culture as the system of personally and collectively accepted meanings of work, operating for a given group at a given time. Work culture is a personal and collective system of acceptance of work operating for a given group at a certain time.

According to the expert explanation above, the definition of work culture can be synthesized as the philosophy adhered to by every individual in performing their work to achive their organization's goals with indicators values of, beliefs in, attitudes towards and habits in a work.

\section{Responsibility}

A teacher literally means an educator of a discipline. In Bahasa, teacher refers to a professional educator responsible for teaching, educating, directing, guiding, assessing, training and evaluating students.

Cornock as quoted by S. K. McGrath and S. J. Whitty states that responsibility means to be responsible for an act one undertakes, while accountability simply means to be called to account. This definition of responsibility is not fully adequate, leaving that the definition of responsible unstated but is not in conflict with the definition derived in this paper. The definition of accountability does not include the positive sense of, i.e., why one would be called to account, but is nevertheless compatible with the tentative definition.

Mullins states, "Responsibility accept a possible reprimand from the manager for involves and obligation by the subordinate to perform certain duties make a certain decision and having in unsatisfactory performance". Ricard L. Daft further defines responsibility as the flip side of the authority coin. Responsibility is the duty to perform the task or activity as assigned. Glover explains that responsibility are moral ones, about which people with different attitudes may legitimately disagree. Besides, in terms of customers, responsibility refers to a customer's partiality as a manifestation of care to avoid or minimize loss or customer unsatisfaction.

According to the explanation above, the definition of responsibility can be synthesized as one's willingness to accept tasks and obligations from an organization leader with the following indicators: performing tasks well, honest, trustworthy and reliable.

\section{Motivation}

The 1950s is a period in which the concepts of motivation were ubiquitous. Three specific theories were formulated over this period: the hierarchy of needs theory, the $\mathrm{X}$ and $\mathrm{Y}$ theory and the two-factor theory. The most popular one is the motivation theory proposed by Abraham Maslow in his book "A Theory of Human Motivation", which is also commonly known as the hierarchy of needs theory. Maslow builds a hierarcy from five levels of basic needs. Outside these needs are higher than 
the existing needs, including the needs for understanding, appreciation and pure spirituality. This perspective is closely associated with Abraham Maslow belief that certain basic needs must be met before higher needs can be satisfied. According to Maslow's hierarchy of needs individual needs must be satisfied in this sequence: Physiological needs such as hunger, thirst, sleep. Safety needs, ensuring survival, such as protection from war and crime. Love and belongingness such as securities, affection and attention from others. Esteem, for example feeling good about oneself. Self-actualization, for example realization of one's potential. It is necessary to identify at which level we are and to focus the fulfilment of the needs above that level from the lowest upwards.

Jason A. Colquitt, Jeffery A. Lepine and Michael J. Wesson define motivation as a set of energetic forces that originates both within and outside an employee, initiates work related effort and determine its direction, intensity and persistence. Fred Luthans defines motivation as a process that starts with physiological or psychological deficiency or need that activates a behavior or a drive that is aimed at a goal or incentive.

According to the concepts above, the definition of motivation can be synthesized as a force that drives one to work persistently and voluntarily in order to achieve the organization's goals with the following indicators: persistence, intiative, intensity.

\section{Research Method}

This research used survey method with path analysis technique (path analyses). The data of this research were collected by selecting the sample in the population. The population in this study is all teachers of Vocational Middle School in Central Jakarta, amounting to 449 teachers. The calculations used slovin; 211 teachers were involved in this study. Data collection used for this research is descriptive statistics and inferential statistics.

\section{Results and Discussions}

\section{Direct Positive Effect of Empowerment on Professional Commitment}

The path coefficient of the effect of empowerment on professional commitment was 0.283 with a $t_{\text {count }}$ value of 5.90 . Since the $t_{\text {count }}$ was greater than the $t_{\text {table }}$ at $d k=207$ for $\alpha=0.05$ by $1.97, H_{0}$ is rejected, while $\mathrm{H}_{1}$ is accepted. This means that the variable empowerment had a significant, direct positive effect on the variable professional commitment. This result is consistent with the statement of some experts, Stephen P. Robbins and Timothy A. Judge, "Psychological empowerment employees belief in the degree to which they affect their work, environment, their competence, the meaningfulness of their job and their perceived authonomy in their works."

\section{Direct Positive Effect of Work Culture on Professional Commitment}

The path coefficient of the effect of work culture on professional commitment was 0.272 with a $t_{\text {count }}$ value of 5.74 . Since the $t_{\text {count }}$ was greater than $t_{\text {table }}$ at $d k=207$ for $\alpha=0.05$ by $1.97, H_{0}$ is rejected, while $\mathrm{H}_{1}$ is accepted. This means that the variable work culture had a significant, direct positive effect on the variable professional commitment. The second hypothesis analysis result shows that work culture had a direct positive effect on professional commitment. According to the finding, it can be concluded that professional commitment was directly and positively affected by work culture. The improvement of work culture will result in improved professional commitment. This result is consistent with the opinion of some experts, Robbins and Lengton, that a strong culture demonstrates high agreement among members about what the organization 
stands for. Such unanimity of purpose builds cohesiveness, loyality, and organizational commitment. These qualities, in turn, lessen employees' tendency to leave the organization. A strong culture demonstrate agreement between teachers' commitments to school. It is tremendously strong that some schools dare to incorporate commitment as one of the prerequisites to hold the titles/positions offered. Although it is a common thing, some teachers still have poor understanding on the meaning of a strong commitment. The understanding on the importance of condusive work conditions leads the school to effective and efficient operation.

\section{Direct Positive Effect of Responsibility on Professional Commitment}

The path coefficient of the effect of responsibility on professional commitment was 0.279 with a $t_{\text {count }}$ value of 5.76. Since the $t_{\text {count }}$ was greater than the $t_{\text {table }}$ at $d k=207$ for $\alpha=0.05$ by $1.97, H_{0}$ is rejected, while $\mathrm{H}_{1}$ is accepted. This means that the variable responsibility had a significant, direct positive effect on the variable professional commitment. The third hypothesis analysis result shows that responbility had a direct positive effect on professional commitment. According to the finding, it can be concluded that professional commitment was directly and positively affected by responsibility. The improvement of responbility will result in improved professional commitment. This result is consistent with the opinion of some experts, including S. Alenxander, that commitment to an organization is encouraged through socially responsible corporate policies and programs that support the community and protect the environment.

\section{Direct Positive Effect of Motivation on Professional Commitment}

The path coefficient of the effect of motivation on professional commitment was 0.286 with a $t_{\text {count }}$ value of 5.54. Since the $t_{\text {count }}$ was greater than the $t_{\text {table }}$ at $d k=207$ for $\alpha=0.05$ by $1.97, H_{0}$ is rejected, while $\mathrm{H}_{1}$ is accepted. This means that the variable motivation had a significant, direct positive effect on the variable professional commitment. The fourth hypothesis analysis result shows that motivation had a direct positive effect on professional commitment. According to the finding, it can be concluded that professional commitment was directly and positively affected by motivation. The improvement of motivation will result in improved professional commitment. Teachers' professional commitment to school generally becomes an important issue. It is tremendously important that even some schools dare to incorporate commitment as one of the prerequisites to hold the titles/positions offered. Although it is a common thing, some teachers still have poor understanding on the meaning of a strong commitment. Thus, in the effort to achieve success and goals, teachers are required to have a strong commitment to the place where they work. This commitment will either motivate or discourage teachers to perform and complete tasks effectively and efficiently. Motivation drives teachers' work productivity/ performance. One of the prerequisites to have high motivation is commitment, which must be taken into account by an organization/school in order to create a harmonious relationship. The school needs teachers who have strong commitment and high motivation to leave a favorable impact.

\section{Conclusion}

Based on the dicsussions, some conclusions can be drawn. First, empowerment has a direct positive effect on professional commitment. This means that an improvement of quality empowerment will result in improved professional commitment. Secondly, work culture has a direct positive effect on professional commitment. This means that empirically, condusive work culture can 
improve professional commitment. Thirdly, responsibility has a direct positive effect on professional commitment. This means that, empirically, responsibility can improve professional commitment. Fourthly, responsibility has a direct positive effect on motivation. This means that, empirically, condusive work culture can improve professional commitment. Suggestions: Firstly, the professional commitment of vocational high school teachers in Central Jakarta Municipality should be improved by giving rewards for achievements and providing facilities and infrastructure sufficiently. Teachers' skills and expertise should be developed through class action research, books, textbooks and other papers. Secondly, improvement of teacher empowerment through specific policies on the minimum service standards for teaching profession that are in accordance with Chapter V Article 46 of Law No. 14 of 2005 on Teachers and Lecturers. In order to improve teachers' commitment, teachers should be assigned with responsibility for conducting instructions based on planning in a more creative and innovative way, so the teachers' attitude towards educational insights and foundations will meet the predetermined standards. Thirdly, every teacher must be committed to improving work culture at the educational unit by developing their academic abilities, attitudes, personalities and moral values. Fourthly, the motivation of vocational school teachers should be improved given that teachers' ability to enrich their teaching methods is still low. Teachers' competencies can be improved through trainings, seminars and knowledge enghancement. Principals should motivate teachers to improve education qualification and academic mastery. Teacher performance reporting on a semiannual or annual basis should be encouraged to measure, control, evaluate and improve teachers' performance. Fifthly, teachers' responsibility to principals should be built through the improvement of credibility and knowledge on principal's tasks so they can establish reliability and build intimacy with lecturers. An open attitude through information improvement in an open and credible way should be encouraged to increase teachers' responsibility to school and stakeholders. The responsibility of the management and teachers should be fostered so they can perform their tasks well, honestly and reliably and have professional commitment to the vision and mission of the education unit (school).

\section{References}

Achua, C. F., Robbert, N. L. (2010). Effective Leadership Fourth Edition. South-Western Cengage Learning,

Anderson, D., Linda, A. A. (2010) Beyond Change Management, Second Edition, Pfeiffer A Wiley Imprint.

Aranya, N., \& Ferris, K. (1984). A Reexamination of Accountants Organizational-Professional Conflict, The Accounting Review, 59,1-14

Ayaz-Alkaya, S., Yaman-Sozbir, S., \& Bayrak-Kahraman, B. (2018). The effect of nursing internship program on burnout and professional commitment. Nurse Education Today, 68, 19-22. https://doi.org/10.1016/j.nedt.2018.05.020.

Bateman, T. S., \& Scoot, A. S. (2015). Management Leading \& Collaborating in a Competitive World. 11 Edition. New York: McGraw-Hill

Bender, M. (2002). Responsibility Counts. Checkerboard Library.

Bernardin, H. J. (2012). Human Resources Management. An Experiential Approach (6th Edition). New York: McGraw-Hill Education.

Bhadury, B. (1992). Work Culture in the Indian Context. Pacific Affairs, 65(1), 112. https://doi.org/10.2307/2760239 
Certo, S. C. (2013). Supervision Concepts and Skill Building (8th Edition). New York: McGraw-Hill.

Colquiit, J. A., \& Jeffery A. L., Michael J. W. (2015). Organizational Behavior Improving Performance and Commitment in the Workplace (4th Edition). New York: McGraw-Hill

Daft, R. L. (2010). New Era of Management (9th Edition). Boston: South Western Cangeage Learning.

Daft, R. L. (2016). Understanding the theory design of organizations (12th Edition). China: South Western Camgage Learning.

Gareth R. J., \& George, J. M. (2012). Understanding and Managing Organizational Behavior (Sixth Edition) Pearson Education.

George, J. M., \& Gareth R. J. (2012). Understanding and Managing Organizational Behavior (6th Edition). Prentice Hall.

George, J. M., \& Gareth R. J. (2015). Understanding and Managing Organizational Behavior $\left(4^{\text {th }}\right.$ Edition). New Jersey: Pearson Prentice Hall.

George, J. M., \& M,Gareth R. J. (2013). Essentials of Contemporary Management (5th Edition). New York: McGraw-Hill.

Gilffords, E. D. (2009). An Examination of Organizational Commitment and Professional Commitment and the Relationship to Work Environment, Demographic and Organizational Factors. Journal of Social Work, 9 (4), 386-404

Glover, J. (1970). Responsibility. London: Routledge and Kegan Paul.

Goetsch, D. L., \& Davis, S. (2013). Quality Management for Organizational Excellence Introduction to Total Quality (Seventh Edition). England: Pearson.

Griffin, R. W., \& Gregory, M. (2014). Organizational Behavior Managing People and Organizations (11th Edition). Canada: South Cengange Learning.

Shamina, H. (2014). Impact Job Satisfaction on Professional Commitment in Higher Education. Galaxy Internasional Interdisciplinary Research Journal. Vol 2 (2).

Haryaka \& Susilowati, Y. (2015). Pengaruh Kompetensi Professional dan Komitmen Organisasional Terhadap Kinerja Guru Dimoderasi Budaya Organisasional. Jurnal Mahasiswa Pasca Sarjana Stikubank.

Hejduk, I. K., Grudzewski, W. M., Sankowska, A., Wańtuchowicz, M. (2009). naczenie zaufania i zarządzania zaufaniem w opinii przedsiębiorstw. E-mentor, 5 (32), Retrieved 3/04/2012, from http://www.e-mentor.edu.pl/artykul/index/numer/32/id/696

Hicks, H., \& Ray, G. G. (1996). Organisasi Teori dan Tingkah Laku, Alih Bahasa Kartasapoetra. Jakarta : Bumi Aksara

Ivancevich, J. M., \& Konopaske, R. (2013). Human Resource Management. New York: McGraw-Hill. Draper, J., \& Fraser, H. (2000). Teaching Commitment and School Development. SAGE Publications. Jhunjhunwala, S. (2012). Review of Indian Work Culture and Challenges Faced by Indians in the Era of Globalisation. Interscience Managent Revier (IMR). 2 (2).

Larsen, R. J., David, M. B. (2014). Personality Psychology Domains of Knowledge About Human Nature (5th Edition). New York: McGraw-Hill.

Leithwood, K., \& Jingping S. (2018). Academic Culture: A Promising Mediator of School Leaders' Influence on Student Learning. Journal of Educational Administration. https://doi.org/10.1108/09574090910954864

Lotze, E. (2004). Work Culture Transformation. German: Die Deutsche Bibliothek.

Lucia R. (2000). Responsibility. USA: Captsone Press. 
Luthans, F. (2011). Organizational Behavior An Evidence Based Approach (12th Edition). New York: McGraw-Hill.

May, L. (1992). Sharing Responsibility. London: The University of Chicago Press.

Malik, O. F., Shahzad, A., Raziq, M. M., Khan, M. M., Yusaf, S., \& Khan, A. (2018). Perceptions of organizational politics, knowledge hiding, and employee creativity: The moderating role of professional commitment. Personality and Individual Differences. 142. 232-237. http://doi:10.1016/j.paid.2018.05.005

McGrath, S. K., \& Whitty, S. J. (2018). Accountability and Responsibility Defined. International Journal of Managing Projects in Business. 11(3). http:// doi: 10.1108/IJMPB-06-2017-0058

Morrow, P. C., \& Goets, Jr. J. F. (1988). Professionalism as a form of work commitment, Journal Of Vocational behavior, 32 (1), 92-111.

Mullins, L. J. (2010). Management \& Organisational Behavior (9th Edition). Prentice Hall: Pearson. Nelson, D. L., \& James C. Q. (2011). Organizational Behavior Science, The Real World and You (7 $7^{\text {th }}$ Edition). USA: South-Western Cengange Learning.

Newstrom, J. W. (2014). Organizational Behaviour Human Behavior at Work (14th Edition). New York: McGraw-Hill.

Noe, R. A., Hollenebeck, J. R., Gehart, B., \& Wright, P. M. (2012). Human Resources Management Gaining Competitive Advantage (8th Edition). Singapore: McGraw-Hill.

Razak, N. A., Darmawan, G. N., \& Keeves, J. P. (2009). Teacher Commitment. In International Handbook of Research on Teachers and Teaching (pp. 343-360). Springer International Publishing.

Mills, P. K., \& Ungson, G. R. (2003). Reassessing the Limits of Structural Empowerment : Organizational Constitution and Trust as Controls. The Academy of Management Review. 28(2). 143-153

Peters, T. J., \& Waterman, R. H. (1982). In search of excellence: Lessons from America's best-run companies. New York: Harper \& Row.

Proenca, T., Torres, A., \& Sampaio, A. S. (2017). Frontline employee empowerment and perceived customer satisfaction. Management Research, 15(2). 187-206. https://doi.org/10.1108/MRJIAM-04-2016-0663

Robbins, S. P., \& Mary, A. C. (2013). Management (12th Edition). England: Pearson.

Robbins, S. P., \& Mary, A. C. (2018). Management (14th Edition). New Jersey : Pearson Prentice Hall. Santrock, J. W. (2012). Educational Psychological (5th Edition). New York: McGraw-Hill.

Fard, S. M. H., Darabi, M., Salimi, M., \& Ramezanpour, M. (2012). The Study of the Relation Between Organizational Commitment and Professional Commitment. Journal of Basic and Applied Scientific Research. 2(7). 6537-6541.

Shafer, W. E., \& Simmons R. S. (2016). Social Responsibility, Professional Commitment and Tax Fraud. Accounting, Auditing \& Accountability Journal. 29(1). 111-134.

Schermerhorn, J. R. (2013). Introduction to Management (12 ${ }^{\text {th }}$ Edition). Asia: John Wiley \& Sons Pte Ltd.

Schneider, B., \& Smith, D. B. (2004). Personality and Organizational Culture. In B. Schneider \& D. B. Smith (Eds.), LEA's organization and management series. Personality and organizations (p. 347-369). Lawrence Erlbaum Associates Publishers.

Singh, K. (2001). Work Values and Work Culture in Indian Organizations Evidence From Automobile industry. India: Delhi Business. 
Slocum, J. W., \& Don, Jr. H. (2011). Principles of Organizational Behavior (13th Edition). China: South Cengange Learning.

Sinha, S., Singh, A. K., Gupta, N., \& Dutt, R. (2010). Impact of Work Culture on Motivation and Performance Level of Employees in Private Sector Companies. Acta Oeconomica Pragensia. 2010(6). 49-67

Vandenberg, R. J., \& Scarpello, V. (1994). A longitudinal assessment of the determinant relationship between employee commitment to the occupation and the organization. Journal of Organizational Behavior. 15. 535-547.

Walton, R. (1979). Work Innovation in the United States. Harvard Business Review. 88-98. 